\title{
Arbuscular Mycorrhizal Fungi Inoculation Reduced the Growth of Pre-Rooted Olive Cuttings in a Greenhouse
}

\author{
João I. Lopes ${ }^{1}$, Carlos M. Correia ${ }^{2}\left(\right.$, Alexandre Gonçalves ${ }^{2,3}$, Ermelinda Silva ${ }^{2}$, Sandra Martins ${ }^{2}(\mathbb{D}$, \\ Margarida Arrobas ${ }^{4}$ and Manuel Ângelo Rodrigues ${ }^{4, *(D)}$ \\ 1 Direção Regional de Agricultura e Pescas do Norte, 5370-347 Mirandela, Portugal; \\ joao.lopes@drapnorte.gov.pt \\ 2 Centre for the Research and Technology of Agro-Environmental and Biological Sciences (CITAB), \\ University of Trás-os-Montes e Alto Douro, 5000-801 Vila Real, Portugal; ccorreia@utad.pt (C.M.C.); \\ agoncalves@morecolab.pt (A.G.); ermelinda07@gmail.com (E.S.); scpmartins@utad.pt (S.M.) \\ 3 Collaborative Laboratory Mountains of Research, Brigantia Ecopark, 5300-358 Bragança, Portugal \\ 4 Centro de Investigação de Montanha (CIMO), Instituto Politécnico de Bragança, Campus de Sta Apolónia, \\ 5300-253 Bragança, Portugal; marrobas@ipb.pt \\ * Correspondence: angelor@ipb.pt
}

check for updates

Citation: Lopes, J.I.; Correia, C.M.; Gonçalves, A.; Silva, E.; Martins, S.; Arrobas, M.; Rodrigues, M.Â.

Arbuscular Mycorrhizal Fungi Inoculation Reduced the Growth of Pre-Rooted Olive Cuttings in a Greenhouse. Soil Syst. 2021, 5, 30. https://doi.org/10.3390/

soilsystems 5020030

Academic Editor: Jan Frouz

Received: 24 March 2021

Accepted: 28 April 2021

Published: 4 May 2021

Publisher's Note: MDPI stays neutral with regard to jurisdictional claims in published maps and institutional affiliations.

Copyright: (c) 2021 by the authors. Licensee MDPI, Basel, Switzerland. This article is an open access article distributed under the terms and conditions of the Creative Commons Attribution (CC BY) license (https:/ / creativecommons.org/licenses/by/ $4.0 /)$.

\begin{abstract}
The effect of commercial mycorrhizal fungi on pre-rooted olive cuttings was assessed. The study consisted of two experiments, the first arranged as a factorial design with three cultivars (Cobrançosa, Madural, and Verdeal Transmontana) and three soil treatments (commercial mycorrhizal fungi, zeolites, and control) and the second as a completely randomized design with three treatments (commercial mycorrhizal fungi, sterilized soil, and control). Cobrançosa grew better than the other cultivars, showing good rooting and initial growth features. Mycorrhizal plants showed reduced growth in comparison to those of the untreated control. This result was explained by competition for photosynthates between plant growth and the expansion of fungi hyphae. Cuttings of reduced leaf area and a twin-wall polycarbonate cover of the greenhouse, somewhat opaque to photosynthetic active radiation, may also have contributed to limit the maximum photosynthetic rate and delay the growth of the inoculated plants. Accordingly, in the mycorrhizal pots, the soil organic carbon (C) increased, probably due to the presence of fungi hyphae in soil samples. Zeolites reduced plant dry matter (DM) yield and tissue phosphorus (P) concentration compared to the control, while increasing the availability in the soil of the cations present in their initial composition. Soil sterilization seems to have reduced soil P bioavailability by inactivating soil enzymes. This study showed that the inoculation with mycorrhizal fungi of pre-rooted cuttings can delay their initial growth. Although these plants may be better prepared to grow in the field, in the short term, their lower development can be a problem for the nurseryman.
\end{abstract}

Keywords: Olea europaea; commercial mycorrizhal fungi; biostimulants; zeolites; soil sterilization; plant growth

\section{Introduction}

Fungi can establish mutualistic associations with higher plants. Some, belonging to the monophyletic phylum Glomeromycota, may form arbuscular structures in the cells of the root cortex to facilitate exchanges of nutrients between the fungus and the host plant. They are known as arbuscular mycorrhizal (AM) fungi, and form with land plants the most widely distributed plant/soil microorganism associations in the rhizosphere [1,2]. The AM fungi may form an extensive network of hyphae in the soil, with increased capacity of water and nutrient uptake, and many other interactions in the rhizosphere benefiting the host plant [3-5].

One of the most documented roles of AM fungi is the supply of $P$ to the host plant. The importance of AM fungi on P uptake was confirmed in several studies irrespective of 
plant species and growing conditions. However, the greatest benefits to plants arise in Plimited soils [6-9]. It is thought that AM fungi can release phosphate enzymes which gives them access to sparingly soluble P sources that non-mycorrhizal plants do not have $[10,11]$. Recent studies have highlighted that, depending on the growing conditions, mycorrhized plants may have privileged access to almost all the essential nutrients [12-15]).

Of relevance to the host plant seems to be the access to water that the extensive network of hyphae of AM fungi provide, which may increase the tolerance of plants to drought stress [5,16,17]. AM fungi can relieve plants from excessive uptake of heavy metals in contaminated soils, restricting their transfer to shoots $[7,18,19]$ or may help plants to cope with saline stress [20]. It was also shown that mycorrhizal symbiosis enhances the ability of plants to cope with biotic stress. Berdeni et al. [21] reported that AM fungal colonization significantly increases resistance of young apple (Mallus pumila) trees to canker (Neonectrina ditissima).

AM fungi increase soil C storage mainly by channeling plant photosynthates into the soil. According to Godbold et al. [22], the mycorrhizal external mycelium is the dominant pathway through which $C$ entered the soil organic matter pool, exceeding the input via leaf litter and fine root turnover. AM fungi may also reduce decomposition of woody plant litter, which also increase soil organic matter and stabilization of $C$ within soil aggregates [23].

AM fungi are obligate biotrophs, inhabiting the root cortical cells and obtaining $\mathrm{C}$ provided by the plant $[3,24]$. This means that plants pay for the valuable services that fungi provide. AM fungi may receive between 10 to $30 \%$ of the plant photosynthates [2]. However, under favorable conditions, plants can obtain the resources they need by their own means, the role of mycorrhiza being less important to the plant. Thus, the plants have a regulatory mechanism to control excessive root colonization known as autoregulation, which allows the host plant to suppress further colonization once a certain level of mycorrhization is reached $[3,25]$. This is probably the reason why under a high concentration of nutrients, the benefits of the symbiosis usually decrease $[8,26]$.

In most studies, the successful use of AM fungi inoculation occurred under severe stress. Olive has received particular attention as it is usually grown in a Mediterranean climate under diverse environmental stresses, such as drought, salinity, and poor soils, which can be alleviated by AM fungi mycorrhization $[17,20,27]$. The nurseries are also places where inoculation with mycorrhizal fungi is typically recommended, as the fungi can benefit the initial growth of young plants in the nursery and the performance of the trees when they are transferred to the field, as reported by Seifi et al. [28] with olive plantlets. However, not all studies show benefits of mycorrhization in nursery olive plants. JiménezMoreno et al. [29] reported a reduction in the shoot growth of mycorrhizal young olive trees without being clear why this happened. Moreover, when commercial mycorrhizal fungi are introduced in the market, the manufacturer tries to popularize their use without ensuring that a benefit to the farmer will occur. Thus, it is important to continue studying the effect of commercial mycorrhizal fungi on nursery plants. In this study, a type of commercial mycorrhizal fungi was used in olive cuttings, after the rooting phase to the first year of growth. The hypothesis is that the use of commercial mycorrhizal fungi, containing five species of AM fungi, can increase the growth of the young plants, reducing the time they spend in the nursery, or increase their final size, making them more valuable in the market.

\section{Materials and Methods}

\subsection{Establishment and Management of the Trials}

Two pot experiments took place in Bragança $\left(41^{\circ} 49^{\prime} \mathrm{N}, 6^{\circ} 46^{\prime} \mathrm{W}\right)$, North-eastern Portugal, in a greenhouse of a commercial nursery. The greenhouse was covered by a double-wall polycarbonate panel. A thermal sensor set at $28{ }^{\circ} \mathrm{C}$ controls the automatic opening of the side and zenith windows. Outside the greenhouse, photosynthetic photon flux density on a typical summer day at solar noon is about $2000 \mu \mathrm{mol} \mathrm{m}^{-2} \mathrm{~s}^{-1}$, when measured with a Ceptometer (AccuPAR, LP-80, Decagon Devices, Pullman, WA, USA). 
Inside the greenhouse, at the same time, the values are slightly less than half ( 45 to $50 \%$ ) as a result of the high thickness and some aging of the cover.

Pre-rooted cuttings of olive (Olea europaea L.) of similar development were selected for these experiments. The selected cuttings showed abundant rooting and a vigorous sprout with three to four new leaves, and were randomly distributed by the experimental treatments.

The growing medium for the development of the pre-rooted cuttings was based on dried $\left(40{ }^{\circ} \mathrm{C}\right)$ and sieved $(2 \mathrm{~mm})$ soil, to which washed quartz sand $(<2 \mathrm{~mm})$ and organic substrate were added to reduce density and increase drainage and aeration. Tubular plastic bags were used, as in the commercial process, which received $3.1 \mathrm{~kg}$ of the mixture soil $(2.23 \mathrm{~kg})$, sand $(0.73 \mathrm{~kg})$, and organic substrate $(0.14 \mathrm{~kg})$. This represents a mixture of 3:1:1 (in volume), representing that which is in use in this greenhouse for commercial purposes. The soil used in the mixtures presented the properties reported in Table 1. The organic substrate was a mixture of coconut fiber, white peat, black peat, composted organic material, perlite, and $1 \mathrm{~g} \mathrm{~L}^{-1}$ of a NPK (15:15:15) fertilizer.

Table 1. Selected properties (average \pm standard deviation; $n=3)$ of the soil $(0-0.20 \mathrm{~m}$ depth) used in the pot experiments.

\begin{tabular}{cccc}
\hline Soil Properties & Value & Soil Properties (Cont.) & Value \\
\hline${ }^{1}$ Clay (\%) & 23.9 & ${ }^{5}$ Extractable $\mathrm{P}\left(\mathrm{mg} \mathrm{P}_{2} \mathrm{O}_{5} \mathrm{~kg}^{-1}\right)$ & $33.1 \pm 2.82$ \\
${ }^{1}$ Silt (\%) & 21.8 & ${ }^{5}$ Extractable $\mathrm{K}\left(\mathrm{mg} \mathrm{K}_{2} \mathrm{O} \mathrm{kg}^{-1}\right)$ & $55.4 \pm 6.13$ \\
${ }^{1} \mathrm{Sand}(\%)$ & 54.3 & ${ }^{6}$ Exch. $\mathrm{Ca}\left(\mathrm{cmol}_{\mathrm{c}} \mathrm{kg}^{-1}\right)$ & $21.7 \pm 0.31$ \\
${ }^{2} \mathrm{pH}\left(\mathrm{H}_{2} \mathrm{O}\right)$ & $6.2 \pm 0.06$ & ${ }^{6}$ Exch. $\mathrm{Mg}\left(\mathrm{cmol}_{\mathrm{c}} \mathrm{kg}^{-1}\right)$ & $5.3 \pm 0.15$ \\
${ }^{2} \mathrm{pH}(\mathrm{KCl})$ & $5.4 \pm 0.12$ & ${ }^{6}$ Exch. $\mathrm{K}\left(\mathrm{cmol}_{\mathrm{c}} \mathrm{kg}^{-1}\right)$ & $0.3 \pm 0.06$ \\
${ }^{3}$ Organic C $\left(\mathrm{g} \mathrm{kg}^{-1}\right)$ & $8.5 \pm 0.21$ & ${ }^{6}$ Exch. Na $\left(\mathrm{cmol}_{\mathrm{c}} \mathrm{kg}^{-1}\right)$ & $0.6 \pm 0.10$ \\
${ }^{4}$ Extractable B $\left(\mathrm{mg} \mathrm{kg}^{-1}\right)$ & $0.8 \pm 0.06$ & ${ }^{7}$ Exch. acidity $\left(\mathrm{cmol}_{\mathrm{c}} \mathrm{kg}^{-1}\right)$ & $0.1 \pm 0.00$ \\
\hline
\end{tabular}

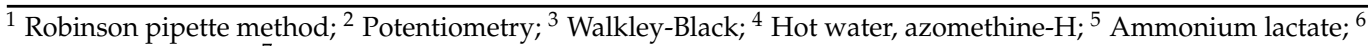
Ammonium acetate; ${ }^{7}$ Potassium chloride.

Experiment 1 consisted of a factorial design with three cultivars crossed with three soil treatments and six replications (six pots). The experiment used the three most widely grown cultivars in the region, Madural, Verdeal Transmontana, hereafter Verdeal, and Cobrançosa. The three soil treatments consisted of the application of a commercial mycorrhizal inoculum incubated in zeolites (Offyougrow Standard), zeolites, and an untreated control (only the commercial growing medium). The zeolites treatment was included to separate the effect of the zeolites from the effect of the mycorrhizal fungi, since the manufacturer of this commercial mycorrhizal inoculum uses zeolites as a carrier for the propagules of the fungi.

The commercial mycorrhizal inoculum consists of zeolites acting as a carrier of propagules (spores, mycelium, and colonized root fragments) of five different species of arbuscular mycorrhizal fungi (Rhizophagus irregularis, Funneliformis mosseae, F. geosporum, F. coronatum, and Claroideoglomus claroideum). In this experiment, $30 \mathrm{~g}$ of commercial product were used per plant, placed beneath the rooting zone, as recommended by the vendor.

The zeolite used in these experiments is a hydrated aluminosilicate of alkaline metals and alkaline earth metals, for which the mineral composition is clinoptilolite (84\%), with a general formula $\left(\mathrm{Ca}, \mathrm{K}_{2}, \mathrm{Na}_{2}, \mathrm{Mg}\right)_{4} \mathrm{Al}_{8} \mathrm{Si}_{40} \mathrm{O}_{96} \cdot 24 \mathrm{H}_{2} \mathrm{O}$, cristobalite (8\%), clay mica (4\%), plagioclase ( 3 to $4 \%$ ), rutile ( 0.1 to $0.3 \%$ ), and quartz (traces). The chemical composition of this zeolite is $\mathrm{SiO}_{2}(65.0-71.3 \%), \mathrm{Al}_{2} \mathrm{O}_{3}(11.5-13.1 \%), \mathrm{CaO}(2.7-5.2 \%), \mathrm{K}_{2} \mathrm{O}(2.2-3.4 \%)$, $\mathrm{FeO}_{3}(0.7-1.9 \%), \mathrm{MgO}(0.6-1.2 \%), \mathrm{Na}_{2} \mathrm{O}(0.2-1.3 \%)$, and $\mathrm{TiO}_{2}(0.1-0.3 \%)$. The ratio $\mathrm{Si} / \mathrm{Al}$ is 4.8 to 5.4. Ion exchangeability is $\mathrm{Ca}^{2+}\left(0.64-0.98 \mathrm{~mol} \mathrm{~kg}^{-1}\right), \mathrm{K}^{+}\left(0.22-0.45 \mathrm{~mol} \mathrm{~kg}^{-1}\right)$, $\mathrm{Mg}^{2+}\left(0.06-0.19 \mathrm{~mol} \mathrm{~kg}^{-1}\right), \mathrm{Na}^{+}\left(0.01-0.19 \mathrm{~mol} \mathrm{~kg}^{-1}\right)$, and cation-exchange capacity (CEC) $\left(1.2-1.5 \mathrm{~mol} \mathrm{~kg}^{-1}\right)$. The zeolite was used in a rate of $30 \mathrm{~g}$ per plant.

Experiment 2 was a completely randomized design with three treatments and six replications. The treatments consisted of the use of (1) the same commercial mycorrhizal inoculum under the conditions reported in the first experiment, (2) sterilized growing 
medium, and (3) an untreated control (only the commercial growing medium). The cultivar used in this experiment was Cobrançosa. The growing medium used in the treatment 2 was autoclaved twice on alternate days for periods of $1 \mathrm{~h}$ at $121^{\circ} \mathrm{C}$ and $105 \mathrm{~Pa}$ of pressure to ensure the destruction of microbial spores. This second experiment was performed having in mind that it could complement the results from the first experiment by comparing growing mediums with only the native microbes, the addition of the commercial inoculum, and a sterilized growing medium.

The experiments were established on 31 January 2017. Thereafter, the pots were kept free from weeds by hand and watered regularly with appropriations of $150 \mathrm{~mL}$ of water. The weekly watering schedule varied greatly over the year, depending on the environmental variables. No further fertilization was provided during the growth period. Plant nutrition was dependent on the nutrients present in the initial growth medium.

\subsection{Leaf Gas Exchange}

Leaf gas exchange measurements were performed in both experiments on 14 September 2017 using a portable IRGA (LCpro+, ADC, Hoddesdon, UK), operating in the open mode. Environmental conditions consisted of a photosynthetic photon flux density of $650 \mu \mathrm{mol} \mathrm{m} \mathrm{m}^{-2} \mathrm{~s}^{-1}$ and an air temperature of $29 \pm 1.2{ }^{\circ} \mathrm{C}$. Net photosynthetic rate (A, $\left.\mu \mathrm{mol} \mathrm{CO} \mathrm{CO}^{-2} \mathrm{~s}^{-1}\right)$, stomatal conductance $\left(\mathrm{g}_{\mathrm{s}}, \mathrm{mmol} \mathrm{H}_{2} \mathrm{O} \mathrm{m}^{-2} \mathrm{~s}^{-1}\right)$, and the ratio of intercellular to atmospheric $\mathrm{CO}_{2}$ concentration $\left(\mathrm{C}_{\mathrm{i}} / \mathrm{C}_{\mathrm{a}}\right)$ were estimated using the equations developed by von Caemmerer and Farquhar [30]. Intrinsic water use efficiency was calculated as the ratio of $\mathrm{A} / \mathrm{g}_{\mathrm{s}}\left(\mu \mathrm{mol} \mathrm{mol}{ }^{-1}\right)$.

\subsection{Soil and Plant Sampling and Analyses}

Data collection from these experiments ended on 20 November 2017, which is more or less the time of the year when cuttings in this nursery begin to be sold to farmers. Firstly, a random soil sample was recovered from each pot. Thereafter, the young plants were separated into roots, stems, and leaves and the following parameters were measured: leaf number per plant and total leaf area (TLA; WinDias image analysis system, Delta-T Devices Ltd., Cambridge, UK). Roots were separated from the soil by using a low-pressure water jet and a $0.6 \mathrm{~mm}$ sieve. The soil was drier at $40{ }^{\circ} \mathrm{C}$ and sieved at $2 \mathrm{~mm}$. The tissue samples were oven dried at $70{ }^{\circ} \mathrm{C}$, weighed, and ground. Based on leaf dry mass and TLA, the leaf mass area (LMA) was calculated. Leaf, stem, and root weight ratio were also calculated.

Soil samples were submitted to the determination of (i) $\mathrm{pH}\left(\mathrm{H}_{2} \mathrm{O}\right.$ and $\mathrm{KCl}$ ) (by potentiometry); (ii) organic C (Walkley-Black method); (iii) cation exchange capacity (ammonium acetate, pH 7.0); (iv) extractable Fe, Mn, Zn, and $\mathrm{Cu}$ (ammonium acetate and EDTA, determined by atomic absorption spectrometry); and (v) soil separates, clay, silt, and sand (Robinson pipette method) [31]; other determinations were (vi) extractable P and K (ammonium lactate solution at $\mathrm{pH}$ 3.7) [32]; and (vii) acid phosphatase activity, determined from the conversion of nitrophenylphosphate to nitrophenolphosphate [33].

Tissue (leaves, stems, and roots) elemental analysis consisted of the determination of ten essential nutrients, such as $\mathrm{N}$ (Kjeldahl), B, and P (colorimetry), and $\mathrm{K}, \mathrm{Ca}, \mathrm{Mg}, \mathrm{Fe}$, $\mathrm{Mn}, \mathrm{Cu}$, and $\mathrm{Zn}$ (atomic absorption spectrophotometry) [34]. Tissue samples were firstly digested with nitric acid in a microwave.

\subsection{Data Analysis}

Data analysis was carried out using JMP14 software (SAS Institute Inc., Cary, NC, USA). Data were firstly tested for normality and homogeneity of variances using the Shapiro-Wilk test and Bartlett's test, respectively. The comparison of the effect of the treatments was provided by two-way (experiment 1 ) and one-way (experiment 2) ANOVA. When significant differences were found $(\alpha<0.05)$, the means were separated by the multiple range Tukey HSD test $(\alpha=0.05)$. 


\section{Results}

\subsection{Plant Dry Matter Yield}

In the factorial experiment, DM yield of Cobrançosa was significantly higher than that of the cultivars, Madural and Verdeal (Figure 1). DM yield varied significantly also with soil treatments, the untreated control showing the higher values and the treatment with mycorrhizal fungi the lower ones. No significant interaction was found between cultivars and soil treatments for any plant part or for total DM yield.

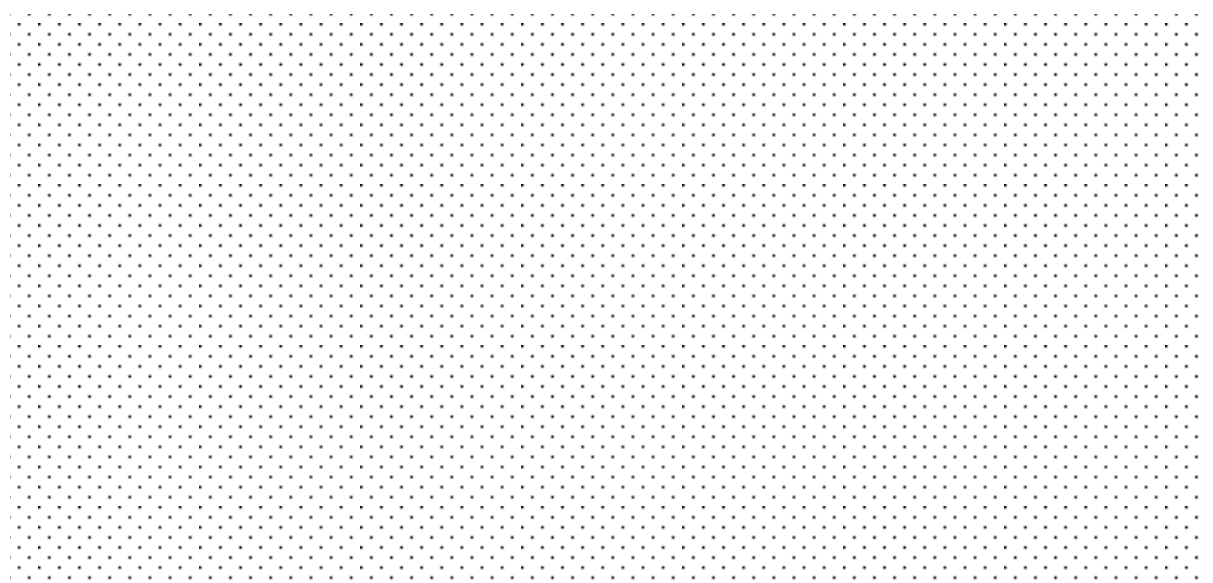

Figure 1. Dry matter yield of young plants separated by roots, stems, and leaves in the factorial design of cultivars $(\mathrm{C}) \times$ soil treatments $(\mathrm{T})$. After ANOVA examination ( $p$, Prob. $>\mathrm{F})$, to each experimental factor (cultivars or soil treatments), and within each plant part (lowercase letters), and total (uppercase letters) means $(n=6)$ followed by the same letter are not significantly different by Tukey HSD test $(\alpha=0.05)$. Vertical bars are the standard errors.

In experiment 2, untreated plants produced significantly higher total biomass than the plants inoculated with mycorrhizal fungi (Figure 2). Plants grown under sterilized soil had average values between the two previously mentioned treatments and without significant differences among them.

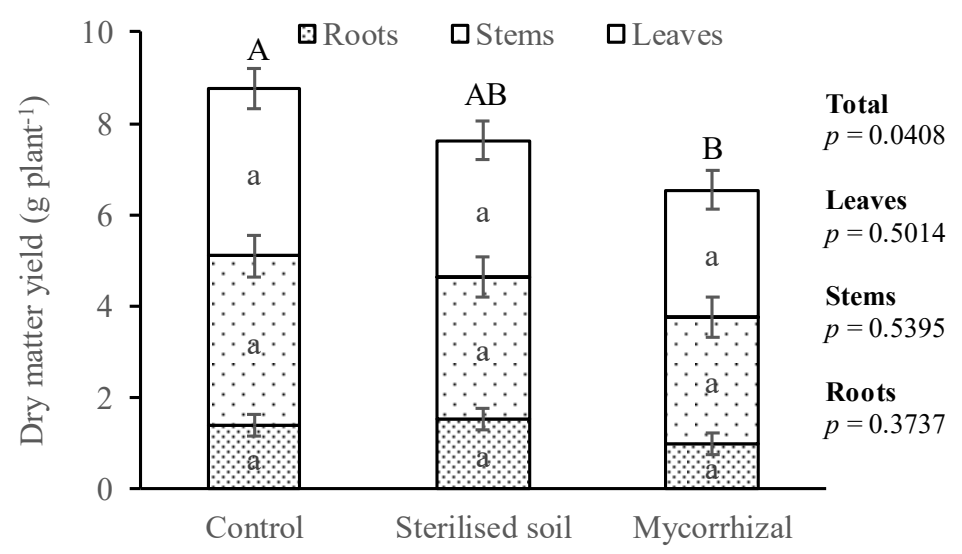

Figure 2. Dry matter yield of young plants separated by roots, stems, and leaves as a function of soil treatments. After ANOVA examination ( $p$. Prob. > F), within each plant part (lowercase letters) and total (uppercase letters) means $(n=6)$ followed by the same letter are not significantly different by Tukey HSD test $(\alpha=0.05)$. Vertical bars are the standard errors.

\subsection{Plant Morphological Traits}

Individual leaf area, total leaf area, leaf mass per area, and leaf weight ratio varied significantly between cultivars, with Cobrançosa showing the higher values (Table 2). Leaf number, individual leaf area, and total leaf area also significantly varied with soil 
treatments. Plants treated with mycorrhizal fungi showed the lower values of leaf number and total leaf area, and plants treated with zeolites showed the lower average values of individual leaf area. Plant part ratios did not vary significantly with soil treatments.

Table 2. Leaf number per plant (LN), individual leaf area (ILA), total leaf area (TLA), leaf mass per area (LMA), leaf weight ratio (LWR), stem weight ratio (SWR), and root weight ratio (RWR) as a function of cultivar and soil amendment.

\begin{tabular}{|c|c|c|c|c|c|c|c|}
\hline & LN & $\begin{array}{c}\text { ILA } \\
\left(\mathrm{cm}^{2}\right)\end{array}$ & $\begin{array}{c}\text { TLA } \\
\left(\mathrm{cm}^{2} \text { plant }^{-1}\right)\end{array}$ & $\begin{array}{c}\text { LMA } \\
\left(\mathrm{g} \mathrm{m}^{-2}\right)\end{array}$ & $\begin{array}{c}\text { LWR } \\
\left(\mathrm{g} \mathrm{g}^{-1}\right)\end{array}$ & $\begin{array}{c}\text { SWR } \\
\left(\mathrm{g} \mathrm{g}^{-1}\right)\end{array}$ & $\begin{array}{c}\text { RWR } \\
\left(\mathrm{g} \mathrm{g}^{-1}\right)\end{array}$ \\
\hline \multicolumn{8}{|l|}{ Cultivar (C) } \\
\hline Madural & $66.7 a^{*}$ & $3.5 \mathrm{~b}$ & $231.4 \mathrm{~b}$ & $137.7 \mathrm{ab}$ & $0.42 \mathrm{c}$ & $0.43 \mathrm{a}$ & $0.15 \mathrm{a}$ \\
\hline Verdeal & $74.7 \mathrm{a}$ & $3.5 \mathrm{~b}$ & $257.1 \mathrm{~b}$ & $133.1 \mathrm{~b}$ & $0.45 \mathrm{~b}$ & $0.41 \mathrm{a}$ & $0.14 \mathrm{a}$ \\
\hline Cobrançosa & $76.9 \mathrm{a}$ & $4.7 \mathrm{a}$ & $350.8 \mathrm{a}$ & $147.8 \mathrm{a}$ & $0.51 \mathrm{a}$ & $0.33 \mathrm{a}$ & $0.16 \mathrm{a}$ \\
\hline \multicolumn{8}{|c|}{ Soil treatment $(\mathrm{T})$} \\
\hline Control & $78.4 \mathrm{a}$ & $4.3 \mathrm{a}$ & $338.2 \mathrm{a}$ & $138.9 \mathrm{a}$ & $0.47 \mathrm{a}$ & $0.39 \mathrm{a}$ & $0.15 \mathrm{a}$ \\
\hline Zeolites & $80.1 \mathrm{a}$ & $3.5 \mathrm{~b}$ & $273.8 \mathrm{ab}$ & $135.9 \mathrm{a}$ & $0.45 \mathrm{a}$ & $0.40 \mathrm{a}$ & $0.15 \mathrm{a}$ \\
\hline Mycorrhizal & $59.8 \mathrm{~b}$ & $3.9 \mathrm{ab}$ & $227.2 \mathrm{~b}$ & $143.7 \mathrm{a}$ & $0.46 \mathrm{a}$ & $0.39 \mathrm{a}$ & $0.15 \mathrm{a}$ \\
\hline Prob. (C) & 0.3276 & $<0.0001$ & 0.0002 & 0.01 & $<0.0001$ & $<0.0001$ & 0.1211 \\
\hline Prob. (T) & 0.0114 & 0.026 & 0.0010 & 0.2557 & 0.5524 & 0.7062 & 0.818 \\
\hline Prob. $(\mathrm{C} \times \mathrm{T})$ & 0.2962 & 0.0129 & 0.4404 & 0.1197 & 0.8832 & 0.6633 & 0.7298 \\
\hline
\end{tabular}

* Means $(n=6)$ followed by the same letter are not significantly different by Tukey HSD test $(\alpha=0.05)$

\subsection{Tissue Nutrient Concentration}

Leaf $\mathrm{N}$ concentration did not vary significantly with cultivar (Figure 3). However, Cobrançosa showed the lower stem and root $\mathrm{N}$ concentrations, significantly different than the values of Verdeal and Madural, respectively. Soil treatments did not influence significantly $\mathrm{N}$ concentration in the leaves, stems, or roots. Root $\mathrm{P}$ concentration decreased significantly from Madural to Verdeal with the lowest values to be found in Cobrançosa. Soil treatments significantly influenced leaf and stem P levels, with the higher values to be found in the control treatments. The lower leaf and stem P levels were found in the zeolites and mycorrhizal treatments, respectively. Root $\mathrm{P}$ levels did not vary significantly with soil treatments. Tissue $\mathrm{K}$ levels varied in a similar trend as tissue $\mathrm{P}$ levels with cultivars. No significant differences between cultivars in leaf and stem $\mathrm{K}$ concentrations were found, and a significant decrease was found from Madural to Cobrançosa in root $\mathrm{K}$ concentrations. Leaf and stem $\mathrm{K}$ concentrations were significantly higher in the zeolites in comparison to the other soil treatments. Root $\mathrm{K}$ levels did not vary significantly with soil treatments. The concentration of the macronutrients $\mathrm{Ca}$ and $\mathrm{Mg}$ and micronutrients $\mathrm{B}, \mathrm{Fe}, \mathrm{Mn}, \mathrm{Cu}$, and Zn often varied significantly with cultivar in the leaves, stems, or roots, but significant differences or consistent trends with soil treatments were not found (data not shown).

In experiment 2, soil treatments did not influence significantly tissue $\mathrm{N}$ concentration (Figure 4). The stems presented particularly lower $\mathrm{N}$ concentrations than the leaves and roots, the later ones displaying similar values. $\mathrm{P}$ concentration varied significantly in all analyzed tissues with soil treatments. Sterilized soil showed the lowest values. No significant differences were found between soil treatments in tissue $\mathrm{K}$ concentrations. The effect of treatments in the other analyzed nutrients $(\mathrm{Ca}, \mathrm{Mg}, \mathrm{B}, \mathrm{Fe}, \mathrm{Mn}, \mathrm{Cu}$, and $\mathrm{Zn}$ ) was minimal, and the results were not presented. 

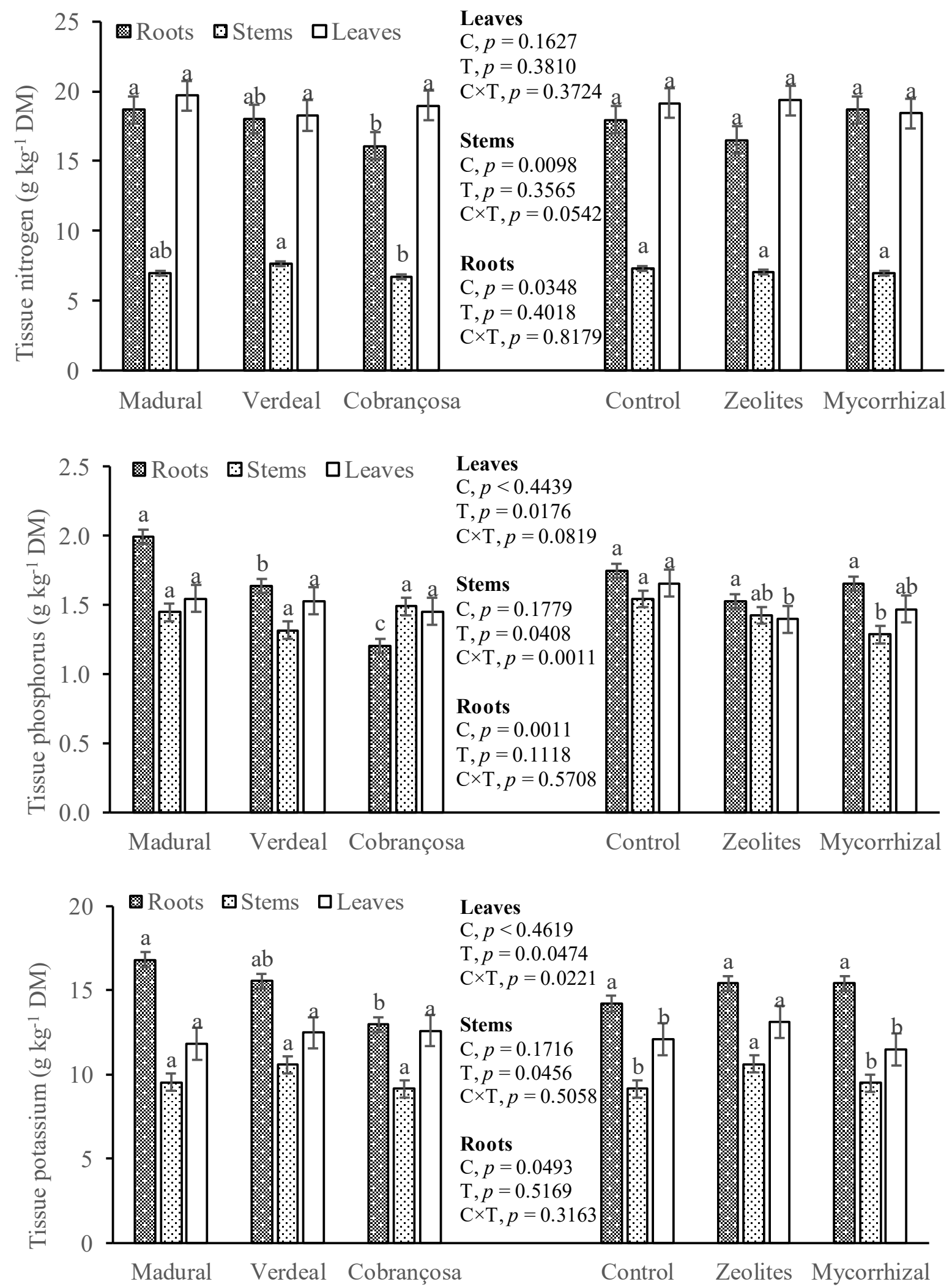

Figure 3. Tissue nutrient concentration in the factorial design of cultivars $\times$ soil treatments. After ANOVA examination $(p$, Prob. $>$ F), to each experimental factor (cultivars (C) or soil treatments $(\mathrm{T}))$, and within each plant part; means $(n=6)$ followed by the same letter are not statistically different by Tukey HSD test $(\alpha=0.05)$. Vertical bars are the standard errors. 

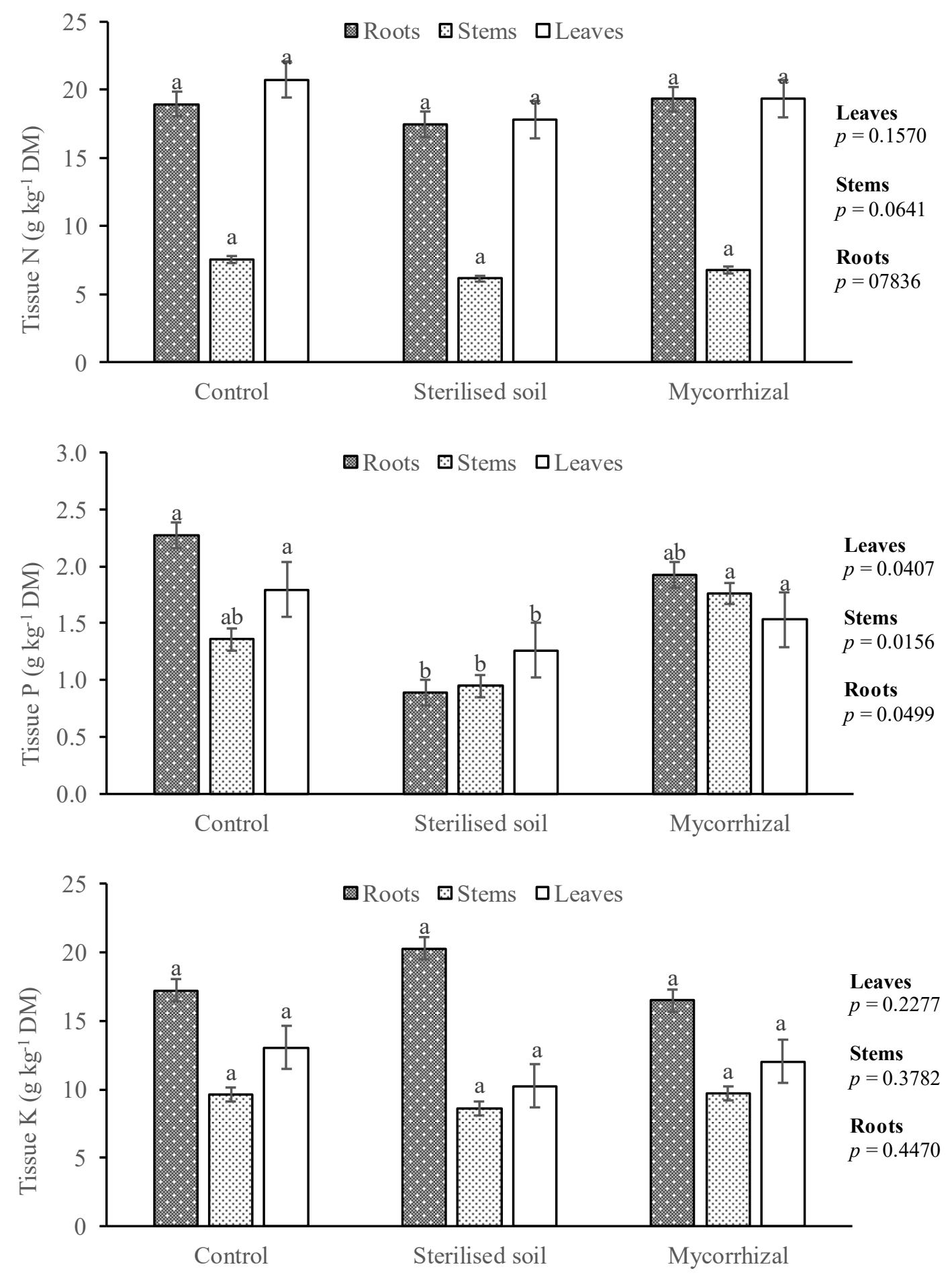

Figure 4. Tissue nutrient concentration as a function of soil treatments. After ANOVA examination $(p$, Prob. $>$ F), within each plant part, means $(n=6)$ followed by the same letter are not significantly different by Tukey HSD test $(\alpha=0.05)$. Vertical bars are the standard errors.

\subsection{Leaf Gas Exchange}

Tables 3 and 4 show the influence of cultivar, soil amendments (experiment 1), and soil treatments (experiment 2) on leaf gas exchange variables. Cobrançosa cultivar had a higher net photosynthetic rate and stomatal conductance than Madural, while A and $\mathrm{g}_{\mathrm{s}}$ of mycorrhizal amendment plants were superior to the other two treatments. In addition, in experiment 2, higher A and $\mathrm{g}_{\mathrm{s}}$ was observed in mycorrhizal than in the other soil treatments. 
Moreover, no significant influence of studied factors was found in both experiments on the $\mathrm{A} / \mathrm{g}_{\mathrm{s}}$ and $\mathrm{C}_{\mathrm{i}} / \mathrm{C}_{\mathrm{a}}$ ratios.

Table 3. Net photosynthetic rate (A), stomatal conductance to water vapor $\left(\mathrm{g}_{\mathrm{s}}\right)$, intrinsic water use efficiency $\left(\mathrm{A} / \mathrm{g}_{\mathrm{s}}\right)$, and ratio of intercellular to atmospheric $\mathrm{CO}_{2}$ concentration $\left(\mathrm{C}_{\mathrm{i}} / \mathrm{C}_{\mathrm{a}}\right)$ as a function of cultivar and soil amendment.

\begin{tabular}{|c|c|c|c|c|}
\hline & $\underset{\left(\mu \mathrm{molm}^{2} \mathrm{~s}^{1}\right)}{\mathbf{A}}$ & $\underset{\left(\mathrm{mmolm}^{2} \mathrm{~s}^{1}\right)}{\mathrm{g}_{\mathrm{s}}}$ & $\begin{array}{c}\mathrm{A} / \mathrm{g}_{\mathrm{s}} \\
\left(\mu \mathrm{mol} \mathrm{mol}{ }^{1}\right)\end{array}$ & $C_{i} / C_{a}$ \\
\hline \multicolumn{5}{|l|}{ Cultivar (C) } \\
\hline Madural & $8.8 b^{*}$ & $127.5 \mathrm{~b}$ & $69.9 \mathrm{a}$ & $0.684 \mathrm{a}$ \\
\hline Verdeal & $9.9 \mathrm{ab}$ & $166.5 \mathrm{ab}$ & $60.3 \mathrm{a}$ & $0.717 \mathrm{a}$ \\
\hline Cobrançosa & $11.0 \mathrm{a}$ & $188.0 \mathrm{a}$ & $63.9 \mathrm{a}$ & $0.699 a$ \\
\hline \multicolumn{5}{|c|}{ Soil treatment $(\mathrm{T})$} \\
\hline Control & $8.7 \mathrm{~b}$ & $137.3 \mathrm{~b}$ & $64.8 \mathrm{a}$ & $0.700 \mathrm{a}$ \\
\hline Zeolites & $8.9 \mathrm{~b}$ & $139.5 \mathrm{~b}$ & $68.4 \mathrm{a}$ & $0.687 a$ \\
\hline Mycorrhizal & $12.1 \mathrm{a}$ & $204.9 \mathrm{a}$ & $60.9 \mathrm{a}$ & $0.712 \mathrm{a}$ \\
\hline Prob. (C) & 0.025 & 0.005 & 0.067 & 0.113 \\
\hline Prob. (T) & $<0.0001$ & $<0.0001$ & 0.185 & 0.267 \\
\hline Prob. $(\mathrm{C} \times \mathrm{T})$ & $<0.0001$ & $<0.0001$ & 0.026 & 0.039 \\
\hline
\end{tabular}

Table 4. Net photosynthetic rate (A), stomatal conductance to water vapor $\left(g_{s}\right)$, intrinsic water use efficiency $\left(A / g_{s}\right)$, and ratio of intercellular to atmospheric $\mathrm{CO}_{2}$ concentration $\left(C_{i} / C_{a}\right)$ as a function of soil treatments.

\begin{tabular}{ccccc}
\hline & $\begin{array}{c}\mathbf{A} \\
\left(\boldsymbol{\mu} \mathbf{m o l m}^{-\mathbf{2}} \mathbf{s}^{-\mathbf{1}}\right)\end{array}$ & $\begin{array}{c}\mathbf{g}_{\mathbf{s}} \\
\left(\mathbf{m m o l m}^{-\mathbf{2}} \mathbf{s}^{-\mathbf{1}}\right)\end{array}$ & $\begin{array}{c}\mathbf{A} / \mathbf{g}_{\mathbf{s}} \\
\left(\boldsymbol{\mu} \mathbf{m o l} \mathbf{~ m o l}^{-\mathbf{1}}\right)\end{array}$ & $\mathbf{C}_{\mathbf{i}} / \mathbf{C}_{\mathbf{a}}$ \\
\hline Control & $10.3 \mathrm{~b}^{*}$ & $180.1 \mathrm{~b}$ & $58.7 \mathrm{a}$ & $0.720 \mathrm{a}$ \\
Sterilised soil & $11.2 \mathrm{ab}$ & $184.9 \mathrm{~b}$ & $58.8 \mathrm{a}$ & $0.719 \mathrm{a}$ \\
Mycorrhizal & $14.2 \mathrm{a}$ & $272.2 \mathrm{a}$ & $54.1 \mathrm{a}$ & $0.732 \mathrm{a}$ \\
Prob. & 0.039 & 0.029 & 0.659 & 0.699 \\
\hline
\end{tabular}

* Means $(n=6)$ followed by the same letter are not significantly different by Tukey HSD test $(\alpha=0.05)$.

\subsection{Soil Properties}

The effect of the cultivar on soil properties was practically nil. However, exchangeable $\mathrm{Ca}$ and consequently CEC were significantly lower in Cobrançosa in comparison to Verdeal pots (Table 5). Soil treatments, in turn, caused a significant impact on soil properties. Organic $\mathrm{C}$ was significantly higher in the mycorrhizal fungi in comparison with the control treatment. $\mathrm{pH}$ was also significantly higher in the mycorrhizal fungi in comparison with the other treatments. Extractable P was also significantly higher in the mycorrhizal treatment, whereas extractable and exchangeable $\mathrm{K}$ were significantly higher in the zeolites treatment. Zeolites pots also showed the higher values of exchangeable $\mathrm{Ca}, \mathrm{Mg}$, and $\mathrm{Na}$, which also demonstrated significantly higher values of CEC in comparison with the other treatments.

In experiment 2, the soil treatments also significantly changed most of the soil properties (Table 6). Organic C did not vary significantly between treatments, but the highest average value was found in the mycorrhizal treatment. The highest average $\mathrm{pH}$ value was also found in the mycorrhizal treatment, as well as extractable $\mathrm{P}$ and $\mathrm{K}$ and exchangeable bases. The treatment prepared from sterilized soil displayed significantly lower values of acid phosphatase activity. 
Table 5. Organic carbon (C), $\mathrm{pH}_{(\mathrm{H} 2 \mathrm{O})}$, extractable phosphorus (P) and potassium (K), exchangeable calcium (Ca), magnesium $(\mathrm{Mg}), \mathrm{K}$ and sodium $(\mathrm{Na})$, cation exchange capacity (CEC), and acid phosphatase activity (APA) in the growing medium at the end of the experiment in the factorial design cultivars $\times$ soil treatments.

\begin{tabular}{|c|c|c|c|c|c|c|c|c|c|c|}
\hline & 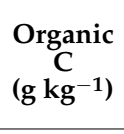 & $\begin{array}{c}\mathrm{pH} \\
\left(\mathrm{H}_{2} \mathrm{O}\right)\end{array}$ & $\begin{array}{l}\text { Extrac. P } \\
(\mathrm{mg} \\
\left.\mathrm{kg}^{-1}\right)\end{array}$ & $\begin{array}{c}\text { Extrac. } \\
\mathbf{K} \\
(\mathrm{mg} \\
\left.\mathrm{kg}^{-1}\right)\end{array}$ & $\begin{array}{c}\text { Exch. Ca } \\
\text { (cmol }_{\mathrm{c}} \\
\left.\mathrm{kg}^{-1}\right)\end{array}$ & $\begin{array}{c}\text { Exch. Mg } \\
\left(\mathrm{cmol}_{\mathrm{c}}\right. \\
\left.\mathrm{kg}^{-1}\right)\end{array}$ & $\begin{array}{c}\text { Exch. K } \\
\left(\mathrm{cmol}_{\mathrm{c}}\right. \\
\left.\mathrm{kg}^{-1}\right)\end{array}$ & $\begin{array}{c}\text { Exch. } \mathrm{Na} \\
\left(\mathrm{cmol}_{\mathrm{c}}\right. \\
\left.\mathrm{kg}^{-1}\right)\end{array}$ & $\begin{array}{c}\mathrm{CEC} \\
\left(\mathrm{cmol}_{\mathrm{c}}\right. \\
\left.\mathrm{kg}^{-1}\right)\end{array}$ & $\begin{array}{c}\text { APA } \\
\left(\mu g g^{-1}\right. \\
\left.h^{-1}\right)\end{array}$ \\
\hline \multicolumn{11}{|l|}{ Cultivar (C) } \\
\hline Madural & $13.4 \mathrm{a} *$ & $6.20 \mathrm{a}$ & $63.4 \mathrm{a}$ & $140.1 \mathrm{a}$ & $9.86 \mathrm{ab}$ & $1.94 \mathrm{a}$ & $0.56 \mathrm{a}$ & $0.44 \mathrm{a}$ & $12.81 \mathrm{ab}$ & $412.5 \mathrm{a}$ \\
\hline Verdeal & $14.3 \mathrm{a}$ & $6.21 \mathrm{a}$ & $70.4 \mathrm{a}$ & $142.8 \mathrm{a}$ & $9.99 \mathrm{a}$ & $1.95 \mathrm{a}$ & $0.50 \mathrm{a}$ & $0.39 \mathrm{a}$ & $12.84 \mathrm{a}$ & $328.8 \mathrm{a}$ \\
\hline \multicolumn{11}{|c|}{ Soil treatment $(\mathrm{T})$} \\
\hline Control & $12.8 \mathrm{~b}$ & $6.19 \mathrm{~b}$ & $49.3 \mathrm{c}$ & $57.4 \mathrm{c}$ & $9.07 \mathrm{~b}$ & $1.78 \mathrm{~b}$ & $0.18 \mathrm{c}$ & $0.31 \mathrm{~b}$ & $11.34 \mathrm{~b}$ & $344.9 \mathrm{a}$ \\
\hline Zeolites & $13.7 \mathrm{ab}$ & $6.15 \mathrm{~b}$ & $68.9 \mathrm{~b}$ & $261.6 \mathrm{a}$ & $10.13 \mathrm{a}$ & $2.02 \mathrm{a}$ & $1.05 \mathrm{a}$ & $0.63 \mathrm{a}$ & $13.84 \mathrm{a}$ & $401.2 \mathrm{a}$ \\
\hline Mycorrhizal & $15.1 \mathrm{a}$ & $6.28 \mathrm{a}$ & $85.1 \mathrm{a}$ & $115.7 \mathrm{~b}$ & $9.57 \mathrm{~b}$ & $1.94 \mathrm{ab}$ & $0.36 \mathrm{~b}$ & $0.34 \mathrm{~b}$ & $12.22 \mathrm{~b}$ & $351.3 \mathrm{a}$ \\
\hline Prob $(C)$ & 0.0833 & 0.9760 & 0.1817 & 0.6900 & 0.0155 & 0.4649 & 0.6025 & 0.6801 & 0.0275 & 0.2774 \\
\hline Prob (T) & 0.0201 & 0.0004 & $<0.0001$ & $<0.0001$ & 0.0314 & 0.0270 & $<0.0001$ & $<0.0001$ & $<0.0001$ & 0.1538 \\
\hline $\operatorname{Prob}(\mathrm{C} \times \mathrm{T})$ & 0.0068 & 0.0035 & 0.0791 & 0.7186 & 0.0625 & 0.0267 & 0.5758 & 0.9758 & 0.0593 & 0.7096 \\
\hline
\end{tabular}

* To each experimental factor (cultivars or soil treatments), means $(n=6)$ followed by the same letter are not significantly different by Tukey HSD test $(\alpha=0.05)$.

Table 6. Organic carbon (C), $\mathrm{pH}_{\left(\mathrm{H}_{2} \mathrm{O}\right)}$, extractable phosphorus $(\mathrm{P})$ and potassium (K), exchangeable calcium (Ca), magnesium $(\mathrm{Mg}), \mathrm{K}$ and sodium $(\mathrm{Na})$, cation exchange capacity (CEC), and acid phosphatase activity (APA) in the growing medium at the end of the experiment.

\begin{tabular}{|c|c|c|c|c|c|c|c|c|c|c|}
\hline & $\underset{\left(\mathrm{g} \mathrm{kg}^{-1}\right)}{\text { Organic }}$ & $\begin{array}{c}\mathrm{pH} \\
\left(\mathrm{H}_{2} \mathrm{O}\right)\end{array}$ & $\begin{array}{c}\text { Extrac. } P \\
(\mathrm{mg} \\
\left.\mathrm{kg}^{-1}\right)\end{array}$ & $\begin{array}{c}\text { Extrac. } \\
\mathrm{K} \\
(\mathrm{mg} \\
\left.\mathrm{kg}^{-1}\right)\end{array}$ & $\begin{array}{c}\text { Exch. Ca } \\
\left(\mathrm{cmol}_{\mathrm{c}}\right. \\
\left.\mathrm{kg}^{-1}\right)\end{array}$ & $\begin{array}{c}\text { Exch. Mg } \\
\left(\mathrm{cmol}_{\mathrm{c}}\right. \\
\left.\mathrm{kg}^{-1}\right)\end{array}$ & $\begin{array}{c}\text { Exch. K } \\
\left(\mathrm{cmol}_{\mathrm{c}}\right. \\
\left.\mathrm{kg}^{-1}\right)\end{array}$ & $\begin{array}{c}\text { Exch. Na } \\
\left(\mathrm{cmol}_{\mathrm{c}}\right. \\
\left.\mathrm{kg}^{-1}\right)\end{array}$ & $\begin{array}{c}\text { CTC } \\
\left(\mathrm{cmol}_{\mathrm{c}}\right. \\
\left.\mathrm{kg}^{-1}\right)\end{array}$ & $\begin{array}{c}\text { APA } \\
\left(\mu g g^{-1}\right. \\
\left.h^{-1}\right)\end{array}$ \\
\hline Control & $12.9 \mathrm{a} *$ & $6.09 \mathrm{~b}$ & $46.1 \mathrm{~b}$ & $56.0 \mathrm{~b}$ & $9.21 \mathrm{ab}$ & $1.82 \mathrm{ab}$ & $0.16 \mathrm{~b}$ & $0.28 \mathrm{a}$ & $11.49 \mathrm{~b}$ & $348.8 \mathrm{a}$ \\
\hline Sterilised soil & $13.3 \mathrm{a}$ & $6.18 \mathrm{ab}$ & $51.4 \mathrm{~b}$ & $69.0 \mathrm{~b}$ & $8.16 \mathrm{~b}$ & $1.61 \mathrm{~b}$ & $0.18 \mathrm{~b}$ & $0.31 \mathrm{a}$ & $10.26 \mathrm{~b}$ & $136.8 \mathrm{~b}$ \\
\hline Mycorrhizal & $14.6 \mathrm{a}$ & $6.29 \mathrm{a}$ & $83.4 \mathrm{a}$ & $100.7 \mathrm{a}$ & $10.55 \mathrm{a}$ & $2.15 \mathrm{a}$ & $0.38 \mathrm{a}$ & $0.36 \mathrm{a}$ & $13.45 \mathrm{a}$ & $418.3 \mathrm{a}$ \\
\hline Prob. & 0.1208 & 0.0107 & 0.0172 & $<0.0001$ & 0.0006 & 0.0011 & $<0.0001$ & 0.0433 & 0.0002 & 0.0005 \\
\hline
\end{tabular}

${ }^{*}$ Means $(n=6)$ followed by the same letter are not significantly different by Tukey HSD test $(\alpha=0.05)$.

\section{Discussion}

Shoot and root DM yields were significantly higher in Cobrançosa in comparison with Madural and Verdeal cultivars. Several other morphological traits, such as individual leaf area and total leaf area, and physiological traits, as net photosynthetic rate, were also significantly higher in the Cobrançosa cultivar. In a previous study, Seifi et al. [28] found similar results, with significant differences on some growth traits and phytochemicals between Valonolia and Koroneiki cultivars inoculated with AM fungi. Some differences between cultivars in tissue elemental composition were also found. Cobrançosa showed a consistent trend for lower tissue $\mathrm{N}$ and for lower $\mathrm{P}$ and $\mathrm{K}$ concentrations than the other cultivars. This result may have two possible causes, some varietal influence or a dilution effect, which occurs due to the increased vegetative growth for similar nutrient availability in the growing medium $[35,36]$.

The comparison between plants treated with commercial mycorrhizal fungi, zeolites, and control revealed significantly higher and lower DM yields, respectively, in the control and mycorrizal fungi treatments. A similar trend was observed in leaf number and in total leaf area, confirming that the dimension of the assimilation area is a determinant to productivity, as leaf area growth determines the light interception capacity of a plant. Negative effects of arbuscular mycorrhizal inoculation on plant growth and biomass accumulation were also reported in other studies $[29,37,38]$. In a similar study using young olive plants grown in pots, Jiménez-Moreno et al. [29] reported that inoculation with Glomus intraradices reduced shoot growth in a P-rich soil. For these authors, it was unclear why this occurred, but in the present study, it seems clear that the problem was competition for photosyntates. The same occurs with nodulated legumes, in which, in the initial phase of rhizobia infection and bacteroid differentiation, the host plant provides the necessary photosynthates without an immediate return $[39,40]$. Arbuscular mycorrhiza is an endosymbiosis in 
which the fungus inhabits the cortical cells of the root. AM fungi are obligate biotrophs, which means that they rely entirely on $C$ from the host plant. It was estimated that the fungus receives between 10 and $23 \%$ of the plants' photosynthetically fixed C [11]. The fungus develops an extensive hyphal network from which the access to water and nutrients will be thereafter facilitated $[3,24]$. The development of the arbuscular structures and the hyphae network requires $C$ from the host plant before it receives benefits from the partnership. Thus, mycorrhized plants would have expended more photosynthates in the development of mycorrhiza than the plants of the control treatment, which probably was the main reason for their reduced growth. Moreover, the smaller total leaf area of mycorrhizal plants decreases their capacity to cope with the increased $\mathrm{C}$ demand due to fungus colonization. It should also be noted that the plants were inoculated at a very young phase, where only 3-4 new leaves were developed, which reduces their ability to provide $\mathrm{C}$ for mycorrhization and their own grown. Another relevant aspect probably was the regular watering and the good nutritional status of the plants in the control treatment, as demonstrated by macronutrients concentrations above the sufficiency range, which might have reduced the benefits of mycorrhization, since it is well documented that it is in stressful growing conditions that plants can benefit more from the establishment of mycorrhizal fungi associations $[16,17,20,41]$. Finally, we should emphasize that the experiment took place in a greenhouse covered by a twin-wall polycarbonate panel. The high thickness of this material reduces the dissipation of thermal radiation but is quite opaque to photosynthetically active radiation (PAR) (more than $50 \%$ of reduction). The low PAR levels reaching the plants limit the maximum photosynthetic rate and the available photosynthates, which also helps to explain the reduced growth of the inoculated plants in comparison to those of the control treatment. The low light relevance as a decisive factor for potential $\mathrm{C}$ cost and gain scenarios of plants associated with AM fungi was also demonstrated previously [42].

Interestingly, the lower biomass production of mycorrhized plants, relatively to control plants, was not due to lower net photosynthesis. Conversely, mycorrhizal-inoculated plants presented higher A, as was the case in the study by Chandrasekaran et al. [42], a response that showed no association with mycorrhizal-mediated macronutrient concentrations, as tissue mineral contents varied little with the soil treatments. Thus, the results suggest that higher net photosynthesis via AM symbiosis was related with the hyphal extensions of mycorrhiza that allow higher hydraulic conductivity, which could result in a better water status of plants [43], an aspect that is supported by the higher stomatal conductance, as well by the lower plant leaf area that provides more water available per unit leaf area, and thus also higher $\mathrm{g}_{\mathrm{s}}$, and with the superior belowground $\mathrm{C}$ sink strength that stimulates photosynthesis by a positive feedback mechanism.

The carbohydrates drain of mycorrhizal fungus contributed to an increase in the soil organic C significantly in the mycorrhizal fungi treatment in comparison to the control, as well as the extractable $\mathrm{P}$ and $\mathrm{K}$ levels, and generally the bases of the exchangeable complex and CEC. The increase of $\mathrm{C}$ in the soil in the pots treated with AM fungi reflects the transfer of photosynthates from the plant to the fungi, whose mycelial structures may have taken part of the analyzed soil samples. It is well known that the mycelium of mycorrhizal fungi is the dominant pathway through which $C$ enters the soil organic matter pool, exceeding the input via leaf litter and fine root turnover [22,23]. The potential benefits of the application of the commercial mycorrhizal fungi also appear to be stressed with the increase in the availability of several other nutrients in the soil, which may reflect their presence in the fungi hyphae or be the result of enzymatic activity, which increased the ease of their extraction with the laboratory extracting agents. However, the activity of acid phosphatase, an enzyme related to soil $\mathrm{P}$ bioavailability, did not significantly vary with soil treatments in this experiment.

The zeolites treatment tended to show lower values of DM yield and of other plant morphological traits than the control treatment. However, leaf and stem $\mathrm{K}$ concentrations were higher in the zeolites than in the other treatments. Leaf P levels were lower in the 
zeolites treatment than in the control. Average tissue Ca levels tended to be the highest in the zeolites-treated plants, although without a significant difference compared to the other treatments. In the soil, the zeolites treatment displayed higher extractable $\mathrm{P}$ and $\mathrm{K}$ values, but also higher values of exchangeable bases in comparison to the control. These zeolites contain $\mathrm{K}$ and other cations in their composition, which may have been the main cause for the increase in $\mathrm{K}$ and Ca levels in the plant and the exchangeable bases in the soil. It is known that zeolites have ion-exchange and adsorption properties [44,45]. Their ability of retaining both cations and anions allowed for the use of zeolites previously enriched in nutrients, including $\mathrm{P}$, as a slow-release nutrient source for plants [46,47]. In these experiments, it seems that the zeolites might have adsorbed $\mathrm{P}$, reducing its availability to plants. However, the extracting agents used in soil analysis might have extracted the recently adsorbed $\mathrm{P}$, which may justify this apparent contradictory result between tissue $\mathrm{P}$ concentration and P extracted from soil samples in the zeolites treatment.

The sterilized soil stood out above all in the reduction of $\mathrm{P}$ in the tissues, although this aspect was not enough to decrease the DM yield of the plants. Acid phosphatase activity was significantly reduced in the treatment using sterilized soil, also demonstrating the association of the activity of this enzyme with soil $\mathrm{P}$ availability to plants $[48,49]$. The soil of the control treatment maintained high levels of acid phosphatase activity, which may mean some mycorrhization with native fungi of this soil. In a similar study, Jiménez-Moreno et al. [29] reported a reduction in shoot growth when a sterilized substrate was used, which led the authors to suggest that the use of natural soil is preferable.

\section{Conclusions}

Contrary to the working hypothesis put forward in this study, the application of commercial mycorrhizal inoculum (Offyougrow Standard) to pre-rooted olive cuttings did not improve their growth in pot experiments carried out in a greenhouse. The DM yield of the treated plants was lower than that of the control. The result was justified by competition for photosynthates between fungi and young plants during the formation of the arbuscular structures and hyphal network. Pre-rooted plants with reduced leaf area and a semi-rigid twin-wall polycarbonate cover of the greenhouse, somewhat opaque to PAR, may also have contributed to reduced potential photosynthetic activity and photosynthates' availability, which delayed the growth of the inoculated plants. The application of mycorrhizal fungi increased soil organic $C$, which probably resulted from fungi hyphae captured in soil samples for analysis. The zeolites treatment reduced leaf P concentration and plant DM yield in comparison to the control. However, it increased $\mathrm{K}$ levels in plants and the levels of most of the cations of the exchangeable complex in the soil. Thus, zeolites appeared to be able to adsorb $\mathrm{P}$ and reduce its availability to plants and to release cations from its initial structure. The sterilization of the growing reduced the concentration of $\mathrm{P}$ in the plant tissues, probably because the reduction in enzymatic activity and consequently in soil $\mathrm{P}$ bioavailability.

Author Contributions: Installation and maintenance of the trials, writing-original draft, J.I.L.; investigation-plant nutrition, writing-review and editing, M.A.; investigation-plant physiology, writing-review and editing, A.G., E.S. and S.M.; conceptualization, funding acquisition, supervision, trial installation and maintenance, writing—review and editing, M.Â.R.; conceptualization, funding acquisition, supervision, trial installation and maintenance, investigation-plant physiology, writingreview and editing, C.M.C. All authors have read and agreed to the published version of the manuscript.

Funding: This research was funded by the Foundation for Science and Technology (FCT, Portugal) and FEDER under Programme PT2020 for financial support to CIMO (UIDB/00690/2020) and CITAB (UIDB/04033/2020). The research was integrated in the activities of the operational group "Novas práticas em olivais de sequeiro: estratégias de mitigação e adaptação às alterações climáticas", funded by PT2020 and EAFRD (European Agricultural Fund for Rural Development).

Institutional Review Board Statement: Not applicable. 
Informed Consent Statement: Not applicable.

Data Availability Statement: Data sharing not applicable. No new data were created or analyzed in this study. Data sharing is not applicable to this article.

Conflicts of Interest: The authors declare no conflict of interest.

\section{References}

1. Bonfante, P.; Perotto, S. Strategies of arbuscular mycorrhizal fungi when infecting host plants. New Phytol. 1995, $130,3-21$. [CrossRef]

2. Lanfranco, L.; Bonfante, P.; Genre, A. The mutualistic interaction between plants and arbuscular mycorrhizal fungi. Microbiol. Spectr. 2016, 4, 1-20. [CrossRef]

3. López-Ráez, J.A.; Pozo, M.J. Chemical signalling in the arbuscular mycorrhizal symbiosis: Biotechnological applications. In Symbiotic Endophytes; Aroca, R., Ed.; Springer: Berlin/Heidelberg, Germany, 2013; pp. 215-232.

4. Calvo-Polanco, M.; Sánchez-Romera, B.; Aroca, R. Arbuscular mycorrhizal fungi and the tolerance of plants to drought and salinity. In Symbiotic Endophytes; Aroca, R., Ed.; Springer: Berlin/Heidelberg, Germany, 2013; pp. 271-288.

5. Luciani, E.; Palliotti, A.; Tombesi, S.; Gardi, T.; Michel, M.; Berrios, J.G.; Zadra, C.; Farinelli, D. Mitigation of multiple summer stresses on hazelnut (Corylus avellana L.): Effects of the new arbuscular mycorrhiza Glomus iranicum tenuihypharum sp. nova. Sci. Hortic. 2019, 257, 108659. [CrossRef]

6. Dag, A.; Yermiyahu, U.; Ben-Gal, A.; Zipori, I.; Kapulnik, Y. Nursery and post-transplant field response of olive trees to arbuscular mycorrhizal fungi in an arid region. Crop Pasture Sci. 2009, 60, 427-433. [CrossRef]

7. Bati, C.B.; Santilli, E.; Lombardo, L. Effect of arbuscular mycorrhizal fungi on growth and on micronutrient and macronutrient uptake and allocation in olive plantlets growing under high total Mn levels. Mycorrhiza 2015, 25, 97-108. [CrossRef]

8. Ortas, I.; Bykova, A. The effect of mycorrhiza inoculation and phosphorus application on phosphorus efficiency of wheat plants. Commun. Soil Sci. Plant Anal. 2018, 49, 1199-1207. [CrossRef]

9. Rodrigues, M.A.; Piroli, L.B.; Forcelini, D.; Raimundo, S.; Domingues, L.S.; Cassol, L.C.; Correia, C.M.; Arrobas, M. Use of commercial mycorrhizal fungi in stress-free growing conditions of potted olive cuttings. Sci. Hortic. 2021, 275, 109712. [CrossRef]

10. Tanwar, A.; Aggarwal, A.; Kaushish, S.; Chauhan, S. Interactive effect of AM fungi with Trichoderma viride and Pseudomonas fluorescens on growth and yield of broccoli. Plant Protect. Sci. 2013, 49, 137-145. [CrossRef]

11. Valentine, A.J.; Mortimer, P.E.; Kleinert, A.; Kang, Y.; Benedito, V.A. Carbon metabolism and costs of arbuscular mycorrhizal associations to host roots. In Symbiotic Endophytes; Aroca, R., Ed.; Springer: Berlin/Heidelberg, Germany, 2013 ; pp. $233-252$.

12. Marschner, H.; Dell, B. Nutrient uptake in mycorrhizai symbiosis. Plant Soil 1994, 159, 89-102. [CrossRef]

13. Koller, R.; Rodriguez, A.; Robin, C.; Scheu, S.; Bonkowski, M. Protozoa enhance foraging efficiency of arbuscular mycorrhizal fungi for mineral nitrogen from organic matter in soil to the benefit of host plants. New Phytol. 2013, 199, 203-211. [CrossRef]

14. Garcia, K.; Zimmermann, S.D. The role of mycorrhizal associations in plant potassium nutrition. Front. Plant Sci. 2014, 17. [CrossRef]

15. Tekaya, M.; Mechri, B.; Mbarki, N.; Cheheb, H.; Hammami, M.; Attia, F. Arbuscular mycorrhizal fungus Rhizophagus irregularis influences key physiological parameters of olive trees (Olea europaea L.) and mineral nutrient profile. Photosynthetica 2017, 55, 308-316. [CrossRef]

16. Ouledali, S.; Ennajeh, M.; Zrig, A.; Gianinazzi, S.; Khemira, H. Estimating the contribution of arbuscular mycorrhizal fungi to drought tolerance of potted olive trees (Olea europaea). Acta Physiol. Plant 2018, 40, 80-93. [CrossRef]

17. Mechri, B.; Tekaya, M.; Attia, F.; Hammami, M.; Chehab, H. Drought stress improved the capacity of Rhizophagus irregularis for inducing the accumulation of oleuropein and mannitol in olive (Olea europaea) roots. Plant Physiol. Biochem. 2020, 156, $178-191$. [CrossRef]

18. Zhan, F.; Li, B.; Jiang, M.; Yue, X.; He, Y.; Xia, Y.; Wang, Y. Arbuscular mycorrhizal fungi enhance antioxidant defence in the leaves and the retention of heavy metals in the roots of maize. Environ. Sci. Pollut. Res. 2018, 25, 24338-24347. [CrossRef] [PubMed]

19. García-Sánchez, M.; Silva-Castro, G.A.; Sanchez, A.; Arriagada, C.; García-Romera, I. Effect of arbuscular mycorrhizal fungi and mycoremediated dry olive residue in lead uptake in wheat plants. Appl. Soil Ecol. 2021, 159, 103838. [CrossRef]

20. Hassena, A.B.; Zouari, M.; Trabelsi, L.; Decou, R.; Amar, F.B.; Chaari, A.; Soua, N.; Labrousse, P.; Khabou, W.; Zouari, N. Potential effects of arbuscular mycorrhizal fungi in mitigating the salinity of treated wastewater in young olive plants (Olea europaea L. cv. Chetoui). Agric. Water Manag. 2021, 245, 106635. [CrossRef]

21. Berdeni, D.; Cotton, T.E.A.; Daniell, T.J.; Bidartondo, M.I.; Cameron, D.D.; Evans, K.L. The effects of arbuscular mycorrhizal fungal colonisation on nutrient status, growth, productivity, and canker resistance of apple (Malus pumila). Front. Microbiol. 2018, 9, 1461. [CrossRef] [PubMed]

22. Godbold, D.L.; Hoosbeek, M.R.; Lukac, M.; Cotrufo, M.F.; Janssens, I.A.; Ceulemans, R.; Polle, A.; Velthorst, E.J.; ScarasciaMugnozza, G.; Angelis, P.; et al. Mycorrhizal hyphal turnover as a dominant process for carbon input into soil organic matter. Plant Soil 2006, 281, 15-24. [CrossRef]

23. Leifheit, E.F.; Verbruggen, E.; Rillig, M.C. Arbuscular mycorrhizal fungi reduce decomposition of woody plant litter while increasing soil aggregation. Soil Biol. Biochem. 2015, 81, 323-328. [CrossRef]

24. Harrison, M.J. Signaling in the arbuscular mycorrhizal symbiosis. Annu. Rev. Microbiol. 2005, 59, 19-42. [CrossRef] 
25. García-Garrido, J.M.; Lendzemo, V.; Castellanos-Morales, V.; Steinkellner, S.; Vierheilig, H. Strigolactones, signals for parasitic plants and arbuscular mycorrhizal fungi. Mycorrhiza 2009, 19, 449-459.

26. Miransari, M. Arbuscular mycorrhizal fungi and uptake of nutrients. In Symbiotic Endophytes; Aroca, R., Ed.; Springer: Berlin/Heidelberg, Germany, 2013; pp. 253-270.

27. Ouledali, S.; Ennajeh, M.; Ferrandino, A.; Khemira, H.; Schubert, A.; Secchi, F. Influence of arbuscular mycorrhizal fungi inoculation on the control of stomata functioning by abscisic acid (ABA) in drought-stressed olive plants. S. Afr. J. Bot. 2019, 121, 152-158. [CrossRef]

28. Seifi, E.; Teymoor, Y.S.; Alizadeh, M.; Fereydooni, H. Olive mycorrhization: Influences of genotype, mycorrhiza, and growing periods. Sci. Hortic. 2014, 180, 214-219. [CrossRef]

29. Jiménez-Moreno, M.J.; Moreno-Márquez, M.C. Moreno-Alías, I.; Rapoport, H.; Fernández-Escobar, R. Interaction between mycorrhization with Glomus intraradices and phosphorus in nursery olive plants. Sci. Hortic. 2018, 233, 249-255. [CrossRef]

30. von Caemmerer, S.; Farquhar, G.D. Some relationships between the biochemistry of photosynthesis and the gas exchange of leaves. Planta 1981, 153, 376-387. [CrossRef] [PubMed]

31. Van Reeuwijk, L.P. Procedures for Soil Analysis, 6th ed.; Technical Paper 9; International Soil Reference and Information Centre: Wageningen, The Netherlands, 2002.

32. Balbino, L.R. La méthode Egner-Riehm et la détermination du phosfore et du potassium «assimilável» des sols du Portugal. In II Col. Medit Cont. Fert. Plantas Cultivadas; Facultad de Ciencias: Sevilla, Spain, 1968; pp. 55-65.

33. Alef, K.; Nannipieri, P.; Trazar-Cepeda, C. Phosphatase activity. In Methods in Applied Soil Microbiology and Biochemistry; Alef, K., Nannipieri, P., Eds.; Academic Press: San Diego, CA, USA, 1995; pp. $214-215$.

34. Temminghoff, E.E.J.M.; Houba, V.G. Plant Analysis Porocedures, 2nd ed.; Klwuwer Academic Publishers: Dordrecht, The Netherlands, 2004.

35. Jarrel, W.M.; Beverly, R.B. The dilution effect in plant nutrition studies. Adv. Agron. 1981, 34, $197-224$.

36. Arrobas, M.; Ferreira, I.Q.; Afonso, S.; Rodrigues, M.A. Sufficiency ranges and crop nutrient removals for peppermint $(M e n t h a \times$ piperita L.) established from field and pot fertilizer experiments. Comm. Soil Sci. Plant Anal. 2018, 49, 1719-1730. [CrossRef]

37. Schroeder, M.S.; Janos, D.P. Phosphorus and intraspecific density alter plant responses to arbuscular mycorrhizas. Plant Soil 2004, 264, 335-348. [CrossRef]

38. Konvalinková, T.; Püschel, D.; Řezáčová, V.; Gryndlerová, H.; Jansa, J. Carbon flow from plant to arbuscular mycorrhizal fungi is reduced under phosphorus fertilization. Plant Soil 2017, 419, 319-333. [CrossRef]

39. Russelle, M.P. Biological dinitrogen fixation in agriculture. In Nitrogen in Agricultural Systems; Schepers, J.S., Raun, W.R., Eds.; Agronomy Monograph no 49; ASA, CSSA, SSSA: Madison, WI, USA, 2008; pp. 281-359.

40. Cooper, J.E.; Scherer, H.W. Nitrogen fixation. In Marschner's Mineral Nutrition of Higher Plants; Marschner, P., Ed.; Elsevier: London, UK, 2012; pp. 389-408.

41. Ortas, I. Role of mycorrhizae on mineral nutrition of fruit trees. Acta Hortic. 2017, 1217. [CrossRef]

42. Bitterlich, M.; Franken, P.; Graefe, J. Atmospheric drought and low light impede mycorrhizal effects on leaf photosynthesis-A glasshouse study on tomato under naturally fluctuating environmental conditions. Mycorrhiza 2019, 29, 13-28. [CrossRef] [PubMed]

43. Chandrasekaran, M.; Chanratana, M.; Kim, K.; Seshadri, S.; Sa, T. Impact of arbuscular mycorrhizal fungi on photosynthesis, water status, and gas exchange of plants under salt stress: A meta-analysis. Front. Plant Sci. 2019, 10, 457. [CrossRef] [PubMed]

44. Ryakhovskaya, N.I.; Gainatulina, V.V. Potato and oat yield in short-cycle crop rotation with zeolite application. Russ. Agric. Sci. 2009, 35, 153-155. [CrossRef]

45. Bernardi, A.C.D.C.; Bezerra, M.; Monte, D.M.; Renato, P.; Paiva, P.; Werneck, C.G. Dry matter production and nutrient accumulation after successive crops of lettuce, tomato, rice, and andropogon grass in a substrate with zeolite. Rev. Bras. Ciênc. Solo 2010, 34, 435-442. [CrossRef]

46. Liator, M.I.; Katz, L.; Shenker, M. The influence of compost and zeolite co-addition on the nutrients status and plant growth in intensively cultivated Mediterranean soils. Soil Use Manag. 2017, 33, 72-80. [CrossRef]

47. Guaya, D.; Mendoza, A.; Valderrama, C.; Farran, A.; Sauras-Year, T.; Cortina, J.L. Use of nutrient-enriched zeolite (NEZ) from urban wastewaters in amended soils: Evaluation of plant availability of mineral elements. Sci. Total Environ. 2020, 727, 138646. [CrossRef]

48. Kieliszewska-Rokicka, B. Phosphate status and acid phosphatase activity in soil and ectomycorrhizas in two mature stands of scots pine (Pinus sylvestris L.) exposed to different levels of anthropogenic pollution. Acta Soc. Bot. Pol. 1999, 68, 311-317. [CrossRef]

49. Egerton-Warburton, L. Aluminum-tolerant Pisolithus ectomycorrhizas confer increased growth, mineral nutrition, and metal tolerance to Eucalyptus in acidic mine soil. Appl. Environ. Soil Sci. 2015, 9, 803821. [CrossRef] 